\title{
ANALIZA DIFERENCIRANOSTI RASTA I FENOLOGIJE PROVENIJENCIJA OBIČNOG BORA (Pinus sylvestris L.) U POKUSU PROVENIJENCIJA KOD KUPRESA (BOSNA I HERCEGOVINA)
}

\section{ANALYSIS OF DIFFERENCES OF GROWTH AND PHENOLOGY OF PROVENANCES OF SCOTS PINE (Pinus sylvestris L.) IN PROVENANCE EXPERIMENT AT KUPRES (BOSNIA AND HERZEGOVINA)}

Dalibor BALLIAN ${ }^{1,2}$, Emir LIZDO³, Faruk BOGUNIĆ ${ }^{1}$

\begin{abstract}
SAŽETAK
U ovom radu analizirano je 15 europskih provenijencija običnog bora u međunarodnom pokusu kod Kupresa. Pokus je osnovan tijekom proljeća 2012. godine sa biljkama starosti dvije godine $(2+0)$.

Ukupno je posađeno 2700 sadnica običnog bora u pokusnom dizajnu slučajnog blok sustava koji je prilagođen terenu, 15 provenijencija u pet ponavljanja ( 5 x 36 sadnica).

Pokus čine provenijencije iz deset europskih zemalja: Austrija (Traisen, Rein, Sistrans), Bosna i Heregovina (Bugojno), Ukrajina (Ivano Frankivsk), Slovačka (Hanusovce), Rumunjska (Sacueini), Norveška (Narvik, Arnes), Njemačka (Teisendorf, Trippstadt), Poljska (Raciane - Nida) i Italija (Ca del Lupo, Fenestrelle, Piani - Valda).

Rezultati morfoloških i fizioloških istraživanja odnose se na razlike preživljivanja, visinama, promjer na vratu korijena i proljetnoj fenologiji otvaranja pupova.
\end{abstract}

KLJUČNE RIJEČl: obični bor (Pinus sylvestris L.), provenijencija, promjer na vratu korijena, visina, fenologija.

\section{UVOD}

\section{INTRODUCTION}

Obični bor (Pinus sylvestris L.) predstavlja jednu od važnijih vrsta crnogorice u šumama Bosne i Hercegovine, a karakterizira ga velika genetska varijabilnost i složena struktura populacija (Stefanović i sur. 1980, Omanović 2008). To je vrsta koja naseljava velike površine, a kao pionirska vrsta podnosi siromašna tla, sušu, vjetar i mraz. Prema preliminarnim rezultatima Druge inventure šuma u Bosni i Hercegovini, površina čistih sastojina običnog bora, proizvodnog karaktera, u Bosni i Hercegovini iznosi 38000 ha (Lojo i Balić 2011). Koliko je značenje ove vrste u našoj zemlji, govori i činjenica da se godišnje proizvede preko pet mili-

1 Prof. dr. Dalibor Ballian, Prof. dr. Faruk Bogunić, Šumarski fakultet Univerziteta u Sarajevu, Zagrebačka 20, 71000 Sarajevo, Bosna i Hercegovina, balliandalibor9@gmail.com

${ }^{2}$ Gozdarski inštitut Slovenije, Večna pot 2, 1000 Ljubljana, Slovenia

${ }^{3}$ Ms. šum. Emir Lizdo, Šumarstvo Prenj Konjic, Bosna i Hercegovina 
juna sadnica običnog bora (Ballian 2000). Kako je drvo običnog bora zbog svoje velike uporabne vrijednosti našlo svoje mjesto u suvremenom proizvodnom šumarstvu, koje se ne može zamisliti bez ove vrste, i njoj je posvećena osobita pozornost (Pintarić 2002). Sve navedeno može se staviti kao razlog zašto na tržištu stalno postoji velika potražnja za ovom vrstom drveta.

Obični bor je najrasprostranjeniji od svih borova (Vidaković i Franjić 2004). Rasprostranjen je u sjevernom dijelu Euroazije, i to od Škotske i Skandinavije na sjeveru Europe do Pirinejskog poluotoka sodvojenim nalazištima na jugu i u srednjem dijelu Španjolske, u Pirinejima, u južnoj i srednjoj Europi, te na jugu u sjevernoj Grčkoj. U sjevernoj Europi, oko Baltika ga nalazimo u ravnicama i pobrežju. U Aziji ga nalazimo u središnjoj i sjevernoj Turskoj i Kavkazu, te iz Urala do sjeverne Mandžurije i Ohotskog mora. U sjevernoj Skandinaviji obični bor ide do $70^{\circ} 20^{\prime}$ sjeverne geografske širine (Vidaković i Franjić 2004). Područje rasprostranjenosti pokriva gotovo $135^{\circ}$ geografske dužine i oko $30^{\circ}$ geografske širine. Pripada euroazijskom flornom elementu (Jovanović 2000).

Visinska rasprostranjenost ovisi o zemljopisnoj širini. $\mathrm{Na}$ Pirinejskom poluotoku u Sierra Nevadi vrsta P. sylvestris obično dolazi od 1600 - $2100 \mathrm{~m}$, u Pirinejima od 970 - 1623 m, u Središnjem masivu od 600 - 1300 m, u Alpama od $1500-2200 \mathrm{~m}$. U Tatrama se rasprostire do $1465 \mathrm{~m}$, u južnoj Norveškoj do $940 \mathrm{~m}$, a na sjeveru Skandinavije do 220 m. Na Balkanskom poluotoku, na planini Pirin rasprostire se u visinu do 2200 m, dok mu je u Maloj Aziji u Turskoj visinska rasprostranjenost sve do $2700 \mathrm{~m}$ (Vidaković i Franjić 2004).

Optimalni uvjeti rasta i razvoja običnog bora nalaze se u nizinama Sjeverne Njemačke i Poljske, Švedske i Rusko sibirskim šumama. Areal običnog bora nije ograničen na izrazite visinske regije, ali na jugu areala zauzima više položaje, a lokalni relikti nalaze se na različitim nadmorskim visinama (Pintarić 2002).

U Bosni i Hercegovini obični bor je rasprostranjen u većem broju manjih populacija, te ne gradi velike kompaktne šumske komplekse (Stefanović 1958). Naime, bosansko-hercegovačke populacije običnog bora odlikuju se vrlo specifičnim morfo-fiziološkim karakteristikama, koje su dobrim dijelom odraz interakcije genoma i ekoloških uvjeta staništa. Tako se njegovo difuzno rasprostiranje može podijeliti na jedanaest većih područja, koja u geografskom i orografskom smislu čine razdvojene cjeline, svaka sa svojim posebnostima (Stefanović 1958), kao i u proizvodnom potencijalu istraživanih provenijencija (Mikić 1991; Ballian i sur. 2009).

Uz navedeno, i fenologija šumskog drveća je važna za otkrivanje postojane veze između klimatskih promjena i fiziološke aktivnosti drveća (Ballian i Kajba 2011). Zbog promjene okolišnih čimbenika uzrokovanih globalnim zagrijavanjem, obični bor migrira prema sjeveru (Eriksson i Ekberg 2001; Nilson i Walfridsson 1995). Ovo kretanje počelo je već u ranijem postglacijalnom periodu, ali je sada intenzivirano. Posljedica ove vrste kretanja, u kojoj vjetar nije glavni medij, diskontinuirana je varijabilnost u smjeru sjever - jug (Eriksson i Ekberg 2001). Sjeverne i kontinentalne populacije zahtijevaju manju temperaturnu sumu za završetak fenofaze i pokazuju veću otpornost. Južne i priobalne provenijencije imaju duži vegetacijski period i manje su otporne na stresne uvijete okoline (Sarvas 1962).

U skladu s tim, nametnula se potreba za testiranjem običnog bora iz različitih država Europe u istim stanišnim uvjetima. Testovi potomstva s običnim borom pokrenuti su relativno davno u europskim okvirima (Giertych 1976, 1992; Nilson 1992; Oleksyn 1988; Prus-Glowacki i sur. 1998), kao rezultat interesa za pojedina obilježja drveća, odnosno u kojoj mjeri su pojedina varijabilna svojstva naslijeđena i prenesena na potomstvo (Vidaković i Krstinić 1985). Ubrzo je došlo i do postavljanja i organiziranja pokusnih ploha širom Europe. Jedna od tih ploha je i ispitivana ploha provenijencija običnog bora na Kupresu.

Cilj ovog istraživanja je ispitati unutarprovenijencijsku i međuprovenijencijsku varijabilnost istraživanih morfoloških i fenoloških svojstava biljaka običnog bora iz 15 europskih provenijencija na pokusnoj plohi kod Kupresa.

\section{MATERIJAL I METODE RADA}

\section{MATERIAL AND METHOD}

Pokusna ploha Kupres osnovana je 2012. godine, sa 15 različitih provenijencija običnog bora porijeklom iz različitih dijelova Europe (Tablica 1). Sama ploha je na nadmorskoj visini 1140 m, nedaleko od grada Kupresa. Podignuta je sadnicama starosti $2+0$, proizvedenim u rasadniku Ajdinovići kod Olova, klasičnim načinom. Sadnja je bila u rupe $30 \times 30 \mathrm{~cm}$, uz razmak između biljaka $2 \times 2 \mathrm{~m}$.

Od tala na mjestu pokusa najzastupljenije su crnice, kalkomelanosoli i smeđa tla ili kalkokambisoli, dok su manje zastupljeni luvisoli i duboka kiselo-smeđa tla u nižim dijelovima pokusa. Prema klasificiranju tipova klime u BiH (Milosavljević 1977) na ovome području vlada planinski tip klime koju karakteriziraju svježa i kraća ljeta, a duge, hladne i vrlo snježne zime. Srednja godišnja temperatura zraka iznosi $6,2^{\circ} \mathrm{C}$, minimalna temperatura izmjerena je u sječnju $\left(-26,8^{\circ} \mathrm{C}\right)$, a maksimalna u kolovozu $\left(34,9^{\circ} \mathrm{C}\right)$. Godišnji prosjek registriranih mrazeva je 155 dana. Prosječna godišnja količina oborina iznosi $1221 \mathrm{~mm}$, a njihova distribucija po godišnjim dobima malo varira (Fenološki godišnjak 2016, 2017 ). Vjetrovi su česti i nerijetko jaki, pa su u zimskom periodu česti veliki snježni zapusi.

Pokus je osnovan u 5 ponavljanja, sa plohicama od 36 biljaka, odnosno po provenijenciji 180 biljka. Oko pokusa je podignut zaštitni pojas sa protupožarnom prugom širine 
Tablica 1. Podaci o istraživanim provenijencije običnog bora

Table 1. Details of the Scots pine provenances studied

\begin{tabular}{|c|c|c|c|c|c|}
\hline $\begin{array}{c}\text { Oznaka na } \\
\text { shemi pokusa }\end{array}$ & $\begin{array}{c}\text { Zemlja } \\
\text { podrijetla }\end{array}$ & $\begin{array}{c}\text { Oznaka } \\
\text { provenijencija }\end{array}$ & $\begin{array}{c}\text { Naziv } \\
\text { provenijencije }\end{array}$ & $\begin{array}{c}\text { Sjeverna } \\
\text { zemljopisna širina }\end{array}$ & $\begin{array}{c}\text { Istočna } \\
\text { zemljopisna dužina }\end{array}$ \\
\hline $\begin{array}{l}\text { Mark of } \\
\text { provenance in plot }\end{array}$ & $\begin{array}{l}\text { Country } \\
\text { of origin }\end{array}$ & $\begin{array}{c}\text { Code for } \\
\text { the provenance }\end{array}$ & $\begin{array}{l}\text { Provenance } \\
\text { name }\end{array}$ & $\begin{array}{l}\text { North } \\
\text { latitude }\end{array}$ & $\begin{array}{c}\text { East } \\
\text { longitude }\end{array}$ \\
\hline 1 & Austrija & $\mathrm{A} 1$ & Kobersdorf/Lackenbach & $47^{\circ} 53^{\prime} 12^{\prime \prime}$ & $15^{\circ} 31^{\prime} 39^{\prime \prime}$ \\
\hline 2 & Austrija & A2 & Urbarialgemeinde Dorfl, Pannholtz, Burgenland & $47^{\circ} 07^{\prime} 14^{\prime \prime}$ & $15^{\circ} 17^{\prime} 14^{\prime \prime}$ \\
\hline 3 & Austrija & A3 & Hochwolkersdorf Stift Reicheresberg & $47^{\circ} 13^{\prime} 49^{\prime \prime}$ & $11^{\circ} 26^{\prime} 14^{\prime \prime}$ \\
\hline 4 & Bosna & B1 & Bugojno & $44^{\circ} 03^{\prime} 00^{\prime \prime}$ & $17^{\circ} 27^{\prime} 00^{\prime \prime}$ \\
\hline 5 & Ukrajina & U1 & Delyatyn & $48^{\circ} 32^{\prime} 41^{\prime \prime}$ & $24^{\circ} 30^{\prime} 10^{\prime \prime}$ \\
\hline 6 & Slovačka & SL1 & Hanušovce & $49^{\circ} 01^{\prime} 35^{\prime \prime}$ & $21^{\circ} 30^{\prime} 01^{\prime \prime}$ \\
\hline 7 & Rumunska & R1 & Sacueni & $47^{\circ} 21^{\prime} 09^{\prime \prime}$ & $22^{\circ} 05^{\prime} 29^{\prime \prime}$ \\
\hline 8 & Norveška & N1 & Narvik & $63^{\circ} 22^{\prime} 22^{\prime \prime}$ & $10^{\circ} 45^{\prime} 03^{\prime \prime}$ \\
\hline 9 & Norveška & N3 & Arnes & $60^{\circ} 7^{\prime} 20^{\prime \prime}$ & $11^{\circ} 27^{\prime} 55^{\prime \prime}$ \\
\hline 10 & Njemačka & NJ1 & Teisendorf & $47^{\circ} 51^{\prime} 00^{\prime \prime}$ & $12^{\circ} 49^{\prime} 00^{\prime \prime}$ \\
\hline 11 & Njemačka & NJ2 & Trippstadt & $49^{\circ} 21^{\prime} 35^{\prime \prime}$ & $07^{\circ} 46^{\prime} 29^{\prime \prime}$ \\
\hline 12 & Poljska & P1 & Raciane - Nida & $53^{\circ} 37^{\prime} 00^{\prime \prime}$ & $21^{\circ} 29^{\prime} 00^{\prime \prime}$ \\
\hline 13 & Italija & I1 & Ca Del Lupo & $43^{\circ} 18^{\prime} 90^{\prime \prime}$ & $13^{\circ} 27^{\prime} 89^{\prime \prime}$ \\
\hline 14 & Italija & 12 & Fenestrelle (To) & $45^{\circ} 01^{\prime} 47^{\prime \prime}$ & $07^{\circ} 03^{\prime} 38^{\prime \prime}$ \\
\hline 15 & Italija & 13 & Piani - Valda (Tn) & $46^{\circ} 13^{\prime} 00^{\prime \prime}$ & $11^{\circ} 16^{\prime} 00^{\prime \prime}$ \\
\hline
\end{tabular}

od $2 \mathrm{~m}$. Sve provenijencije posađene su u slučajnom blok rasporedu, uz odstupanja od prvobitnog plana zbog pojave stajaće vode (slika 1. i 2).

Ocjena preživljenja, mjerenje visina, promjera na vratu korijena i praćenje fenoloških promjena provedeni su u 2016. i 2017. godini. U studenom 2016. godine mjerene su visine i promjeri na vratu korijena svih sadnica običnog bora. Mjerenje je provedeno digitalnim pomičnim mjerilom sa toč-

\begin{tabular}{|c|c|c|c|c|c|c|c|c|}
\hline 8 & 15 & 7 & \multicolumn{6}{|c|}{ Pokus običnog bora kod Kupresa } \\
\hline 12 & 1 & 2 & 3 & 4 & 5 & 6 & 7 & 8 \\
\hline 6 & 9 & 10 & 11 & 12 & 13 & 14 & 15 & 3 \\
\hline 8 & 3 & 4 & 5 & 6 & 7 & 8 & 9 & 10 \\
\hline 1 & 11 & 12 & 13 & 14 & 15 & 13 & 1 & 2 \\
\hline 9 & 5 & 6 & 7 & & & 10 & 11 & 12 \\
\hline 4 & 13 & 14 & 15 & & & 2 & 3 & 4 \\
\hline 3 & 7 & 8 & 9 & 10 & & & 13 & 14 \\
\hline 11 & 15 & 2 & 1 & 14 & & & 5 & 6 \\
\hline 5 & 9 & 10 & 11 & 12 & & & & \\
\hline 4 & 1 & 2 & & & & & & \\
\hline
\end{tabular}

Slika 1. Shema pokusa kod Kupresa

Figure 1. Layout of planting of Scots pine provenances near Kupres nošću $0,1 \mathrm{~mm}$. Praćenje fenoloških promjena trajalo je 56 dana, točnije od 26.04. 2017. godine do 21.06.2017. godine, a vršeno je na način da su se podaci sa plohe prikupljali odlascima na lokaciju svakih 7 do 10 dana.

Fenologija istraživanih provenijencija pratila se u 6 karakterističnih fenofaza, od uspavanog (zimskog) pupa do potpuno razvijenog pupa i to: A. Uspavani pupoljak (zimski pupoljak, tamno smeđe boje); B. Početak razvoja pupa (pupoljci bubre, žućkasto - zelene boje, imaju opnu koju vršci iglica još nisu probili); C. Intenzivno izduživanje pupa (pupoljci izduženi, žućkasto - zelenkaste boje); D. Početak otvaranja iglica i dodatno izduživanje pupa (jasno se vide iglice

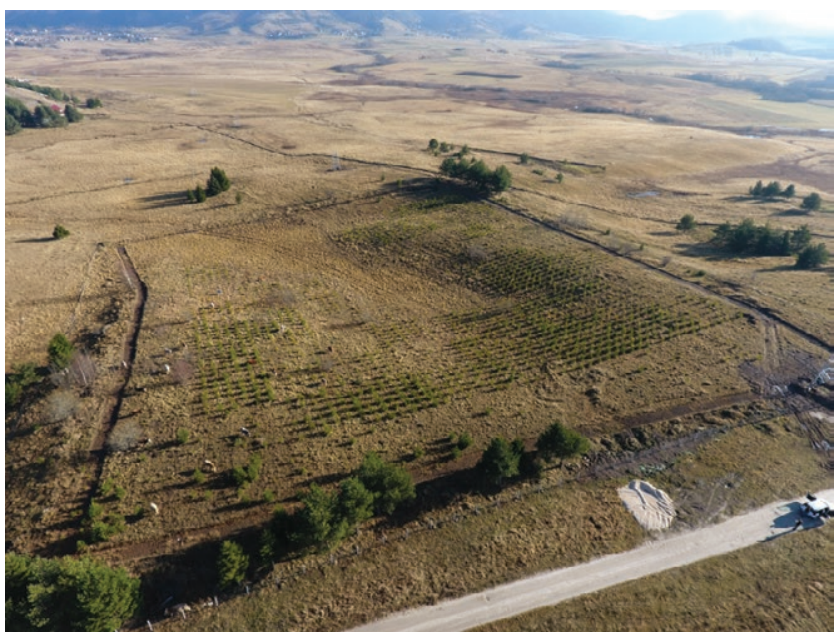

Slika 2. Pokusna ploha kod Kupresu (Studeni 2016.)

Figure 2. Experimental site near Kupres (November 2016) 


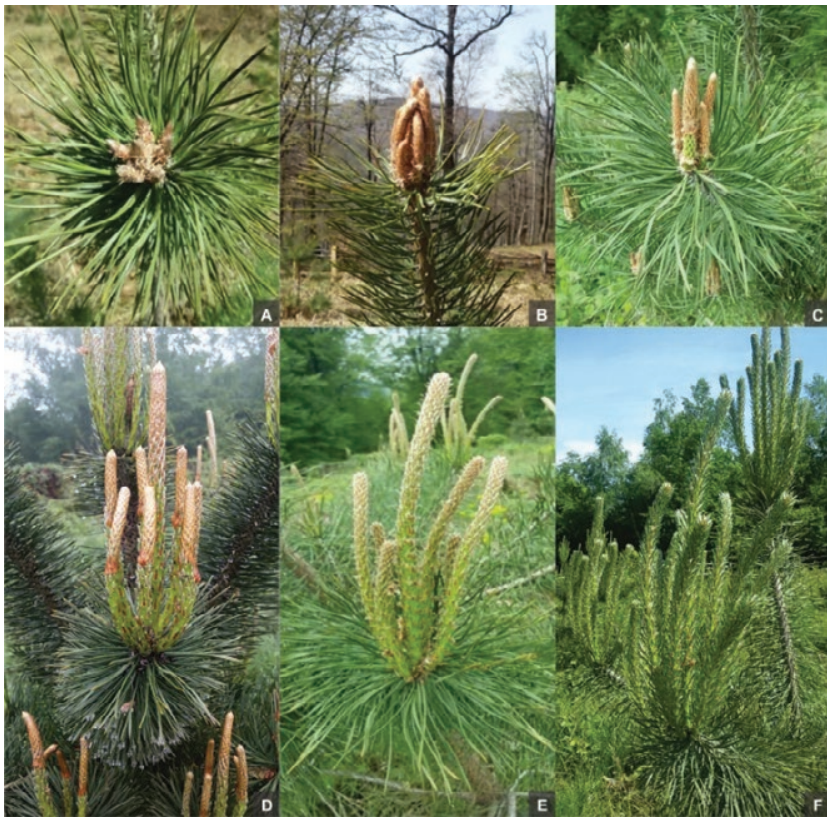

Slika 3. Fenološke faze (Ballian i Šito 2017)

Figure 3. Observed phenophases (Ballian i Šito 2017)

zelene boje, visine oko $10 \mathrm{~cm}$ ); E Završetak razvoja iglica i završno izduživanje pupa (pupoljci su otvoreni, visine oko $15 \mathrm{~cm}$ ); Potpuno razvijene iglice (iglice zelene boje jasno razvijene) (Slika 3).

Mjereni podaci o visinama i promjerima na vratu korijena statistički su obrađeni korištenjem paketa IBM SPSS Statistics 20 i Microsoft Excel 2010. Analize obuhvaćaju: Unutarpopulacijsku i međupopulacijsku varijabilnost kvantitativnih svojstava (visina i promjera na vratu korijena) kroz standardne pokazatelje: srednju (prosječnu) vrijednost, standardnu devijaciju, minimalnu i maksimalnu vrijednost i koeficijent varijacije; Analizu varijance (ANOVA) za kvantitativna svojstva (visina i promjer na vratu korijena); Multipla testiranja radi prikazivanja razlika između grupa (nakon utvrđivanja statistički značajnih razlika analizom varijance po nekom ispitivanom svojstvu); Multipla testiranja za kvantitativna svojstva: Duncanov test.

\section{REZULTATI RESULTS}

\section{Preživljenje biljaka - Survival of plants}

Rezultati analize preživljenja biljaka do 2016. godine prikazani su u tablici 2. Od ukupno 2700 posađenih sadnica različitih provenijencija običnog bora u međunarodnom pokusu na Kupresu, u 2017. godini postotak uspjeha sadnje iznosio je 67\%. U periodu od 2012. godine kada su biljke posađene, pa do 2017. godine kada je provedeno ispitivanje, preživjelo je 1830 biljaka.

Iz tablice 2 se vidi da je najveći broj preživjelih biljaka do 2017. godine imala provenijencija Austrija A1, dok najmanji broj preživjelih biljaka ima provenijencija Italija I1, dok je bilo za očekivati da će najlošije preživljavanju imati provenijencije sa sjevera Europe. Ipak štetni učinci prenošenja provenijencija sa sjevera na jug, anulirani su visokom nadmorskom visinom i kratkim vegetacijskim periodom.

\section{Analiza promjera na vratu korijena - Analysis of the root colar diameter}

Korištena je deskriptivna statistika kako bi se utvrdila srednja vrijednost promjera na vratu korijena biljke, minimalne

Tablica 2. Statistički pokazatelji preživljenja i promjera na vratu korijena. Table 2. Statistical indicators of survival and diameter on the root neck.

\begin{tabular}{|c|c|c|c|c|c|c|}
\hline $\begin{array}{l}\text { Provenijencija } \\
\text { Provenance }\end{array}$ & $\begin{array}{c}\text { Broj zasađenih } \\
\text { biljaka } \\
\begin{array}{c}\text { Number of planted } \\
\text { plants }\end{array}\end{array}$ & $\begin{array}{l}\text { Broj preživjelih } \\
\text { biljaka } \\
\text { Number of } \\
\text { surviving plants }\end{array}$ & $\begin{array}{l}\text { Prosječni promjer } \\
\text { Average diameter }\end{array}$ & $\begin{array}{c}\text { Standardna } \\
\text { devijacija } \\
\text { Standard deviation }\end{array}$ & $\begin{array}{l}\text { Minimum } \\
\text { Minimum }\end{array}$ & $\begin{array}{l}\text { Maksimum } \\
\text { Maximum }\end{array}$ \\
\hline Austrija A1 & 180 & 158 & 4,07 & 2,13 & 1,4 & 9,3 \\
\hline Austrija A2 & 180 & 149 & 3,85 & 2,25 & 0,5 & 4,0 \\
\hline Austrija A3 & 180 & 145 & 3,36 & 1,19 & 0,9 & 6,2 \\
\hline Bosna B1 & 180 & 130 & 3,23 & 1,14 & 1,0 & 5,8 \\
\hline Ukrajina U1 & 180 & 121 & 3,83 & 2,25 & 0,8 & 6,8 \\
\hline Slovačka SL1 & 180 & 129 & 3,30 & 1,29 & 0,5 & 6,7 \\
\hline Rumunjska R1 & 180 & 121 & 3,38 & 1,24 & 0,7 & 6,8 \\
\hline Norveška N1 & 180 & 92 & 1,19 & 0,60 & 0,3 & 3,9 \\
\hline Norveška N2 & 180 & 131 & 2,23 & 0,86 & 0,8 & 4,8 \\
\hline Njemačka NJ1 & 180 & 136 & 3,08 & 1,17 & 0,8 & 6,1 \\
\hline Njemačka NJ2 & 180 & 124 & 3,24 & 1,07 & 0,9 & 5,2 \\
\hline Poljska P1 & 180 & 140 & 3,38 & 0,97 & 0,5 & 5,8 \\
\hline Italija I1 & 180 & 64 & 1,84 & 0,70 & 0,5 & 4,0 \\
\hline Italija I2 & 180 & 93 & 2,39 & 0,95 & 0,5 & 4,5 \\
\hline Italija I3 & 180 & 97 & 2,49 & 1,00 & 0,7 & 5,3 \\
\hline Ukupno - Total & 2700 & 1830 & 3,11 & 1,92 & 0,3 & 9,3 \\
\hline
\end{tabular}


Tablica 3. Analiza varijance za promjer na vratu korijena

Table 3. Analysis of variance for the root neck diameter

\begin{tabular}{|c|c|c|c|c|c|}
\hline $\begin{array}{l}\text { Svojstvo } \\
\text { Traits }\end{array}$ & $\begin{array}{l}\text { Izvor variranja } \\
\text { Variation source }\end{array}$ & $\begin{array}{l}\text { Suma kvadrata } \\
\text { Sume of squares }\end{array}$ & $\begin{array}{c}\text { Stupnjevi slobodež } \\
\text { Df. }\end{array}$ & $\begin{array}{c}\text { Sredina kvadrata } \\
\text { Average of the square. }\end{array}$ & $\mathrm{F}$ \\
\hline Promjer & Između grupa & 960,98 & 14 & 68,64 & 21,31 \\
\hline Diameter & Unutar grupa & 5835,39 & 1812 & 3,22 & \\
\hline (cm) & Ukupno & 6796,37 & 1826 & & \\
\hline
\end{tabular}

i maksimalne vrijednosti promjera, te standardna devijacija i koeficijent varijacije. Srednje vrijednosti promjera na vratu korijena kreću se u intervalu od $1,19 \mathrm{~cm}$ (Norveška N1), do $4,07 \mathrm{~cm}$ (Austrija A1). Osim provenijencije Austrija A1, nema provenijencija sa prosječnim promjerom na vratu korijena iznad $4,00 \mathrm{~cm}$. Većina provenijencija imaju srednji promjer u intervalu između 2,20 i $3,90 \mathrm{~cm}$, tim više što od pola od ukupnog broja provenijencija ima srednji promjer iznad 3,00 cm. Srednji promjer svih biljaka je $3,11 \mathrm{~cm}$.

Kada pogledamo vrijednosti standardne devijacije, vidimo da je ona kod 12 provenijencija sa vrijednosti ispod 2,00 $\mathrm{cm}$, dok je samo kod provenijencije Austrija A1 $(2,63 \mathrm{~cm})$, Austrija A2 $(3,25 \mathrm{~cm})$ i Ukrajina $(3,65 \mathrm{~cm})$ iznad, što je ujedno i najveća vrijednost standardne devijacije. Ukupna standardna devijacija za pokus iznosi $1,92 \mathrm{~cm}$.

Najmanja vrijednost promjera na vratu korijena zabilježena je kod jedne biljke provenijencije Norveška N1 i iznosi 0,30 $\mathrm{cm}$, dok je najveća vrijednost promjera na vratu korijena zabilježena kod provenijencije Austrija A1 i iznosi 9,30 cm. Analizom varijance promjera na vratu korijena dobivene su statistički značajne razlike između istraživanih provenijencija, što je prikazano u tablici 3.

Iz rezultata Duncan testa vidi se da imamo 6 skupina, a među njima se provenijencija Norveška N1 izdvaja u zasebnu skupinu. Tako, kada je u pitanju vrijednost promjera na vratu korijena ona nema povezanost sa ostalim provenijencijama sa tipičnom vrijednošću promjera od $1,195 \mathrm{~cm}$, što je i bilo za očekivati kod ove sjeverne provenijencije (Tablica 4).

\section{Analiza visina biljaka - Analysis of the height of plants}

Kao i za vrijednosti promjera na vratu korijena različitih provenijencija, deskriptivnom statistikom utvrđena je srednja vrijednost visine biljaka, minimalne i maksimalne vrijednosti te standardna devijacija. Najveću srednju vrijednost visine biljaka imala je provenijencija Poljska P1 (116,26 $\mathrm{cm})$, a zatim slijedi Ukrajina U1 $(114,20 \mathrm{~cm})$. Najmanju prosječnu visinu sadnica ima provenijencija Norveška N1, a koja iznosi 40,52 cm.

Tablica 4. Prikaz skupina kod Duncan testa za svojstvo promjera korijenskog vrata

Table 4. View the group at Duncan's test for the diameter of the root neck.

\begin{tabular}{|c|c|c|c|c|c|c|c|}
\hline \multicolumn{8}{|c|}{$\begin{array}{c}\text { Promjer - Diameter (cm) } \\
\text { Duncan }\end{array}$} \\
\hline \multirow{2}{*}{$\begin{array}{l}\text { Provenijencija } \\
\text { Provenance }\end{array}$} & \multirow{2}{*}{$\mathrm{N}$} & \multicolumn{6}{|c|}{ Subset for alpha $=0,05$} \\
\hline & & 1 & 2 & 3 & 4 & 5 & 6 \\
\hline Norveška N1 & 92 & 1,19 & & & & & \\
\hline Italija I1 & 64 & & 1,84 & & & & \\
\hline Norveška N2 & 131 & & 2,23 & 2,23 & & & \\
\hline Italija I2 & 93 & & & 2,39 & & & \\
\hline Italija I3 & 97 & & & 2,49 & & & \\
\hline Njemačka NJ1 & 136 & & & & 3,08 & & \\
\hline Bosna B1 & 130 & & & & 3,23 & & \\
\hline Njemačka NJ2 & 124 & & & & 3,24 & & \\
\hline Slovačka SL1 & 129 & & & & 3,30 & & \\
\hline Austrija A3 & 145 & & & & 3,36 & 3,36 & \\
\hline Poljska P1 & 140 & & & & 3,38 & 3,38 & \\
\hline Rumunjska R1 & 121 & & & & 3,38 & 3,38 & \\
\hline Ukrajina U1 & 121 & & & & & 3,83 & 3,83 \\
\hline Austrija A2 & 149 & & & & & 3,85 & 3,85 \\
\hline Austrija A1 & 155 & & & & & & 4,10 \\
\hline Sig & & 1,00 & 0,10 & 0,29 & 0,28 & 0,06 & 0,29 \\
\hline
\end{tabular}


Tablica 5. Statistički pokazatelji vrijednosti visina. Table 5. Statistical indicators of height values.

\begin{tabular}{|c|c|c|c|c|}
\hline $\begin{array}{l}\text { Provenijencija } \\
\text { Provenance }\end{array}$ & $\begin{array}{c}\text { Prosječna } \\
\text { visina } \\
\text { Average } \\
\text { height }\end{array}$ & $\begin{array}{l}\text { Standardna } \\
\text { devijacija } \\
\text { Standard } \\
\text { deviation }\end{array}$ & $\begin{array}{l}\text { Minimum } \\
\text { Minimum }\end{array}$ & $\begin{array}{l}\text { Maksimum } \\
\text { Maximum }\end{array}$ \\
\hline Austrija A1 & 112,61 & 28,62 & 45 & 188 \\
\hline Austrija A2 & 113,23 & 27,78 & 24 & 182 \\
\hline Austrija A3 & 106,61 & 33,58 & 34 & 183 \\
\hline Bosna B1 & 99,50 & 32,77 & 22 & 181 \\
\hline Ukrajina U1 & 114,20 & 29,44 & 30 & 187 \\
\hline Slovačka SL1 & 108,75 & 39,23 & 25 & 210 \\
\hline Rumunjska R1 & 107,72 & 35,87 & 4 & 223 \\
\hline Norveška N1 & 40,52 & 16,19 & 10 & 105 \\
\hline Norveška N2 & 75,76 & 23,96 & 25 & 143 \\
\hline Njemačka NJ1 & 105,20 & 36,08 & 18 & 207 \\
\hline Njemačka NJ2 & 105,06 & 32,10 & 39 & 180 \\
\hline Poljska P1 & 116,26 & 29,18 & 29 & 183 \\
\hline Italija I1 & 59,69 & 20,06 & 26 & 103 \\
\hline Italija I2 & 71,03 & 23,32 & 24 & 136 \\
\hline Italija I3 & 81,48 & 26,97 & 30 & 144 \\
\hline Ukupno - Total & 98,10 & 36,36 & 4 & 223 \\
\hline
\end{tabular}

Od ukupno izmjerenih 1830 sadnica, najmanja sadnica ima visinu od 4,00 cm i pripada provenijenciji Rumunjska R1, a maksimum, odnosno najveća vrijednost visine jedne biljke izmjerena je također u provenijenciji Rumunjska R1 i iznosi $223 \mathrm{~cm}$ (Tablica 5). Osim ove provenijencije jedino još provenijencije Njemačka NJ1 i Slovačka SL1 imaju najveće sadnica sa vrijednošću visine od preko $200 \mathrm{~cm}$, a njihove vrijednosti su $210 \mathrm{~cm}$ za provenijenciju Slovačka SL1 i $207 \mathrm{~cm}$ za provenijenciju Njemačka NJ1. Jedina provenijencija uz Rumunjsku R1 čije vrijednosti iznose manje ili jednako $10 \mathrm{~cm}$ je Norveška N1, koja ujedno ima i najmanju prosječnu vrijednost visine biljaka. Srednja vrijednost visina svih biljaka u pokusu iznosi $98,10 \mathrm{~cm}$,

Kada pogledamo vrijednosti standardne devijacije, vidimo da ona kod deset provenijencija ima vrijednost ispod $30 \mathrm{~cm}$, dok kod ostalih pet provenijencija vrijednost standardne devijacije iznosi iznad $30 \mathrm{~cm}$, Najmanju vrijednost standardne devijacije za visinu ima provenijencija Norveška N1 i ona iznosi $16,19 \mathrm{~cm}$ (jedina koja ima vrijednost standardne devijacije ispod $20 \mathrm{~cm}$ ), dok najveću vrijednost standardne devijacije ima provenijencija Slovačka SL1 $(39,23 \mathrm{~cm})(\mathrm{Ta}-$ blica 5). Ukupna standardna devijacija svih 1830 sadnica iznosi $36,36 \mathrm{~cm}$.

U tablici 5 jasno možemo vidjeti da najveću srednju vrijednost visine ima provenijencija Poljska P1, ali da je uz jako malu razliku prate provenijencije Austrija A1 i Austrija A2 te Ukrajina U1, dok ubjedljivo najmanju srednju vrijednost visine sadnica, što je jasno vidljivo, ima provenijencija Norveška N1.

Analiza varijance za vrijednosti visina pokazuje da postoji statistički značajna razlika između prosječnih visina različitih provenijencija uz vjerovatnost od $95 \%$ (Tablica 6).

Daljnja potvrda varijabilnosti provenijencija dobivena je pomoću Duncanovog testa. Razlike između grupa su značajne, a razlike unutar grupa su slučajne. Ovim testom provenijencije su grupirane u osam skupina. Jednu skupinu gradi od jedne do sedam provenijencija, a posebno se ističu provenijencija Norveška N1 i Italija I1, jer svaka od njih gradi posebnu skupinu, što je i za očekivati s obzirom na male srednje veličine (Tablica 7).

\section{Fenološka istraživanja - Phenological research}

Rezultati fenoloških promatranja baziraju se na podacima koji su prikupljeni tijekom jedne godine, od 26.04.2017. do 21.06.2017. godine. Tijekom ovog perioda praćeno je šest standardiziranih fenofaza (Ballian i Šito 2017).

Na dan 20. travnja za sve provenijencije je registrirana faza A, sve provenijencije su imale uspavani zimski pupoljak. 21. lipnja zabilježeno je da su biljke svih petnaest istraživanih provenijencija ušle u posljednju fazu, odnosno da imaju u potpunosti formirane iglice zelene boje.

Na temelju fenoloških promatranja kao početak vegetacije običnog bora (fenološka faza početak razvoja pupoljka) u međunarodnom pokusu na Kupresu može se uzeti 26. Travanj, jer je kod tri provenijencije ovog dana počelo otvaranje pupova, Za ostalih trinaest provenijencija datum početka prve fenofaze bio je 3. svibanj 2017. Početak završne fenofaze, dakle pojave prvih formiranih iglica za provenijencije Austrija A3, Bosna B1 i Norveška N2 zabilježen je datum 1. lipanj. Najkasniju pojavu pretposljednje faze, faze E imali smo 21. lipnja kod jedanaest provenijencija.

U određenim vremenskim intervalima uočena je prisutnost istovremeno čak četiri fenofaze na pokusnoj plohi, dok su

Tablica 6. Analiza varijance za visine

Table 6. Analysis of variance for the height

$\begin{array}{lccccc}\text { Svojstvo } & \text { Izvor variranja } & \text { Suma kvadrata } & \text { Stupnjeva slobode } & \text { Sredina kvadrata } & \text { F } \\ \text { Traits } & \text { Variation source } & \text { Sume of squares } & \text { Df } & 14 & \text { Average of the square. }\end{array}$


Tablica 7. Prikaz skupina prema prosječnim vrijednostima visina

Table 7. View the group at Duncan's test for the diameter of the height.

\begin{tabular}{|c|c|c|c|c|c|c|c|c|c|}
\hline \multicolumn{10}{|c|}{$\begin{array}{c}\text { Visina - Height (cm) } \\
\text { Duncan }\end{array}$} \\
\hline \multirow{2}{*}{$\begin{array}{l}\text { Provenijencija } \\
\text { Provenance }\end{array}$} & \multirow{2}{*}{$\mathrm{N}$} & \multicolumn{8}{|c|}{ Subset for alpha $=0,05$} \\
\hline & & 1 & 2 & 3 & 4 & 5 & 6 & 7 & 8 \\
\hline Norveška N1 & 92 & 40,52 & & & & & & & \\
\hline Italija I1 & 64 & & 59,69 & & & & & & \\
\hline Italija I2 & 93 & & & 71,03 & & & & & \\
\hline Norveška N2 & 131 & & & 75,76 & 75,76 & & & & \\
\hline Italija I3 & 97 & & & & 81,48 & & & & \\
\hline Bosna B1 & 130 & & & & & 99,50 & & & \\
\hline Njemačka NJ2 & 124 & & & & & 105,06 & 105,06 & & \\
\hline Njemačka NJ1 & 136 & & & & & 105,20 & 105,20 & & \\
\hline Austrija A3 & 145 & & & & & 106,61 & 106,61 & 106,61 & \\
\hline Rumunjska R1 & 121 & & & & & 107,72 & 107,72 & 107,72 & 107,72 \\
\hline Slovačka SL1 & 129 & & & & & & 108,75 & 108,75 & 108,75 \\
\hline Austrija A1 & 155 & & & & & & 113,14 & 113,14 & 113,14 \\
\hline Austrija A2 & 149 & & & & & & 113,23 & 113,23 & 113,23 \\
\hline Ukrajina U1 & 121 & & & & & & & 114,20 & 114,20 \\
\hline Poljska P1 & 140 & & & & & & & & 116,26 \\
\hline Sig & & 1,000 & 1,000 & 0,236 & 0,151 & 0,065 & 0,077 & 0,097 & 0,060 \\
\hline
\end{tabular}

Tablica 8. Prikaz razvoja promatranih fenofaza u 2017, godini.

Table 8. Development of observed phenophases in 2017, year.

\begin{tabular}{|c|c|c|c|c|c|c|c|c|c|c|c|c|c|}
\hline \multirow{3}{*}{$\begin{array}{l}\text { Red. br. } \\
\text { Mark of } \\
\text { provenance } \\
\text { in plot }\end{array}$} & \multirow{3}{*}{$\begin{array}{c}\text { Provenijencija } \\
\text { Provenance }\end{array}$} & \multicolumn{12}{|c|}{ Fenofaza - početak i završetak fenološke faze / Phenophaza - the start and end of the phenolic phase } \\
\hline & & \multicolumn{2}{|c|}{ A } & \multicolumn{2}{|c|}{$\mathrm{B}$} & \multicolumn{2}{|c|}{ C } & \multicolumn{2}{|c|}{$\mathrm{D}$} & \multicolumn{2}{|c|}{$\mathrm{E}$} & \multicolumn{2}{|c|}{$\mathrm{F}$} \\
\hline & & $\mathrm{N}_{\mathrm{R}}$ & $\mathrm{N}_{\mathrm{k}}$ & $\mathrm{N}_{\mathrm{R}}$ & $\mathrm{N}_{\mathrm{k}}$ & $\mathrm{N}_{\mathrm{R}}$ & $\mathrm{N}_{\mathrm{k}}$ & $\mathrm{N}_{\mathrm{R}}$ & $N_{k}$ & $N_{R}$ & $\mathrm{~N}_{\mathrm{k}}$ & $\mathrm{N}_{\mathrm{R}}$ & $\mathrm{N}_{\mathrm{k}}$ \\
\hline 1 & Austrija A1 & / & 12.05. & 03.05. & 22.05. & 12.05. & 01.06. & 22.05. & 09.06. & 22.05. & 21.06 & 09.06. & / \\
\hline 2 & Austrija A2 & / & 12.05. & 03.05. & 22.05. & 22.05. & 01.06 & 22.05. & 09.06 & 01.06. & 21.06 & 09.06 & / \\
\hline 3 & Austrija A3 & l & 12.05. & 26.04. & 12.05. & 03.05. & 22.05. & 22.05. & 01.06. & 22.05. & 09.06. & 01.06 & / \\
\hline 4 & Bosna B1 & / & 12.05. & 03.05. & 12.05. & 03.05. & 22.05. & 12.05. & 01.06 & 22.05. & 09.06 & 01.06 & / \\
\hline 5 & Ukrajina U1 & / & 12.05. & 03.05. & 22.05. & 22.05. & 01.06. & 22.05. & 09.06. & 01.06. & 21.06 & 09.06 & / \\
\hline 6 & Slovačka SL1 & I & 12.05. & 03.05. & 22.05. & 12.05. & 01.06. & 22.05. & 09.06. & 22.05. & 21.06. & 09.06 & / \\
\hline 7 & Rumunjska R1 & / & 12.05 & 03.05. & 22.05. & 22.05. & 01.06. & 22.05. & 09.06. & 22.05. & 21.06 & 09.06 & / \\
\hline 8 & Norveška N1 & / & $12.05-$ & 03.05. & 22.05. & 22.05. & 01.06. & 22.05. & 09.06. & 01.06. & 21.06 & 09.06 & / \\
\hline 9 & Norveška N2 & / & 03.05. & 26.04. & 12.05. & 03.05. & 12.05. & 12.05. & 01.06. & 22.05. & 09.06 & 01.06 & / \\
\hline 10 & Njemačka NJ1 & / & 03.05. & 26.04. & 12.05. & 03.05. & 12.05. & 22.05. & 09.06. & 22.05. & 09.06 & 09.06 & / \\
\hline 11 & Njemačka NJ2 & / & 12.05 & 03.05 & 12.05. & 12.05. & 01.06. & 22.05 & 09.06 . & 22.05 & 21.06 & 09.06 & l \\
\hline 12 & Poljska P1 & / & 12.05 & 03.05 & 22.05 & 03.05. & 12.05. & 22.05. & 09.06 & 22.05 & 21.06. & 09.06. & I \\
\hline 13 & Italija I1 & I & 12.05 & 03.05. & 01.06 & 22.05 & 09.06. & 01.06 & 09.06. & 01.06 & 21.06 & 09.06 & l \\
\hline 14 & Italija I2 & / & 12.05 & 03.05 & 22.05 & 12.05 & 01.06. & 22.05 & 09.06 . & 01.06. & 21.06. & 09.06 & l \\
\hline 15 & Italija I3 & / & 12.05 & 03.05. & 22.05 . & 12.05. & 01.06 & 22.05. & 09.06. & 22.05 & 21.06. & 09.06. & l \\
\hline
\end{tabular}


najčešće bile prisutne istovremeno po tri fenofaze, što je bilo za očekivati s obzirom na podrijetlo provenijencija. Također su razlike primijećene i unutar provenijencija, a to sve ukazuje na široku individualnu genotipsku varijabilnost biljaka analiziranih unutar provenijencije (populacije), tako da različiti genotipovi imaju različitu normu reakcije na manje - više iste ili vrlo slične ekološke uvijete tijekom jedne sezone. Prvi rezultati promatranja fenoloških obilježja otvaranja pupova i formiranja iglica pokazuju da je potrebno ova promatranja provoditi u kontinuitetu, kako bi se procijenilo uspijevanje i genetička varijabilnost provenijencija, utvrdila ukupna genetska raznolikost običnog bora te ponašanje pojedinih provenijencija na danom lokalitetu.

\section{RASPRAVA DISCUSSION}

Obični bor je ograničen određenim čimbenicima koji utječu na njegov prirast i prinos. Posebno je ograničenje vodni režim tla (Kramer i Kozlowski 1960) koji utječe na razvoj običnog bora. Suše i visoke temperature predstavljaju, nekada periodičan, a svakako najčešći problem za obični bor, usprkos suvremenim metodama predviđenim u primjeni mjera ublažavanja posljedica.

Ovim istraživanjem obuhvaćeno je 15 različitih provenijencija običnog bora na pokusnoj plohi na Kupresu. U periodu od 2012. godine kada su biljke posađene, pa do 2017. godine kada je ispitivanje provedeno, preživjelo je 1830 sadnica, od ukupno 2700 posađenih. $U$ analizu su uzete u obzir sve preživjele biljke svih provenijencija. Možemo reći da je postotak preživljivanja iznosio $67,70 \%$. Svaka od provenijencija je pokazala različit postotak preživljenja na ovoj pokusnoj plohi te su razlike među provenijencijama lako uočljive, a vezane su za podrijetlo provenijencija. Postotak preživjelih sadnica je u padu, jer prema podacima od prije 2 godine (Ballian i sur. 2017), u 2015. godini postotak preživljivanja bio je 73,10 $\%$. Primjenom deskriptivne analize dobiveni su rezultati morfoloških istraživanja, te podaci o prosječnim svojstvima sadnica običnog bora., Utvrđeno je da su prosječne vrijednosti za svih 1830 sadnica iznosile $98,11 \mathrm{~cm}$ za visinu sadnica, a za promjer na vratu korijena biljke $3,11 \mathrm{~cm}$, a i ova su svojstva vezana za podrijetlo provenijencija.

Prema Müller-Strack i sur. (1992) vrste sa disjunktnim rasprostiranjem, kao što je obični bor, pokazuju veliku međupopulacijsku varijabilnost na morfološkoj razini. Ovo istraživanje je upravo pokazalo među provenijencijsku varijabilnost, kroz analizu varijance, kao i što su u drugim pokusima s običnim borom dobili Oleksyn (1988), Giertych (1992), Nilson (1992), Ballian i Šito (2017). Tako se promatranjem morfoloških parametara mogu dobiti važne informacije o adaptivnosti jedinke ili provenijencije, a to se ponajprije ogleda u morfološkoj raznolikosti, prosječnim vrijednostima, varijanci, koeficijentu varijabilnosti te ostalim statističkim parametrima (Erikson i Egberg 2001).
Giertych (1976) na osnovi podataka o rasama običnog bora smatra da se najbolje rase mogu naći u istočnom dijelu središnje Europe (Latvija, Bjelorusija, Poljska), a neke od njih su i predmet našeg istraživanja, te provenijencija Poljska pokazuje superiornost u visinskom prirastu. Od te središnje regije kvaliteta rasa običnog bora se smanjuje u svim smjerovima. Važna karakteristika tog srednjoeurpskog bora je da ima posebno veliku adaptabilnost (Giertych 1976; Vidaković i Krstinić 1985; Prus-Glowacki i sur. 1998), a to posebno vrijedi za obični bor iz Latvije i sjeveroistočnog područja Poljske.

Rezultati ovog istraživanja potvrdili su ove navode, jer je obični bor porijeklom iz Poljske, odnosno iz provenijencije Poljska P1, imao najveću prosječnu visinu koja je iznosila $116,26 \mathrm{~cm}$, Također, visoke prosječne vrijednosti visine pokazale su biljke koje dolaze iz zemalja koje se nalaze u blizini Poljske, te u samom središtu Europe. Tako provenijencije Austrija A1 $(112,61)$ i Austrije A2 $(113,23)$ imaju treću i četvrtu najveću srednju vrijednost visine na ovoj eksperimentalnoj plohi. S druge strane, što se više pomičemo prema sjeveru, konkretno do Norveške, vidjet ćemo osjetan pad vrijednosti prosječne visine biljke, pa kod provenijencije Norveška N1 imamo vrijednost od 40,52 cm. Za istu provenijenciju je zabilježena i najmanja vrijednost za prosječni promjer na vratu korijena koja iznosi $1,19 \mathrm{~cm}$. Ovo potvrđuje ranije rezultate do kojih su došli Giertych (1976) i Ballian i Šito (2017). Istom logikom možemo reći da je ovaj autor bio upravu i za provenijencije koje dolaze iz južnijih zemalja, pa tako provenijencija Italija I1 koja se nalazi najjužnije od svih, ima srednju vrijednost promjera na vratu korijena koja iznosi $1,848 \mathrm{~cm}$, što je druga najmanja vrijednost u ovom pokusu, odmah poslije provenijencije Norveška N1. Srednja vrijednost visine sadnica za ovu provenijenciju iznosi 59,69 cm, što je također druga najmanja srednja vrijednost visine među svim provenijencijama.

Iako se na osnovi jednogodišnjih fenoloških istraživanja ne mogu donositi opći zaključci o fenološkim karakteristikama istraživanih provenijencija i zakonitosti koje u pogledu sezonskih promjena vegetacije vladaju na različitim lokalitetima. Dobiveni rezultati mogu poslužiti kao dobra osnova u daljnjim proučavanjima kako bi se procijenilo uspijevanje i genetska varijabilnost domaćih i stranih provenijencija, utvrdila ukupna genetska raznolikost običnog bora u Europi i ponašanje pojedinih provenijencija u različitim stanišnim uvjetima.

\section{ZAKLJUČCI CONCLUSION}

Ukupan broj mjerenih sadnica je 1830, pri čemu je postotak preživljenja u 2017. godini iznosio $67,70 \%$, te se kreće u intervalu od 35,50 \% (Italija I1) do 87,70 \% (Austrija A1).

Deskriptivnom analizom promjera na vratu korijena utvrđeno je da najveću vrijednost srednjeg promjera ima provenijencija Austrija A1 (4,07 cm), Najmanju vrijednost pro- 
sječnog promjera na vratu korijena imaju biljke provenijencije Norveška N1 $(1,19 \mathrm{~cm})$, Vrijednosti promjera na vratu korijena kretale su se od $0,30 \mathrm{~cm}$ za provenijenciju Norveška N1, što predstavlja minimum, do $9,30 \mathrm{~cm}$ za provenijenciju Austrija A1, što predstavlja maksimum kada su u pitanju vrijednosti prosječnog promjera na vratu korijena. Sa prosječnom visinom od $116,26 \mathrm{~cm}$ provenijencija Poljska P1 pokazuje najveću prosječnu vrijednost za svojstvo visina, dok biljke iz provenijencije Norveška N1 imaju najmanju prosječnu vrijednost za visinu koja iznosi $40,52 \mathrm{~cm}$.

Sva istraživanja pokazala su analizom varijance da su prisutne statistički značajne razlike između istraživanih provenijencija, a što je potvrđeno i Duncanovim testom.

Na osnovi provedene analize, može se zaključiti da se na osnovi visine samo provenijencije Norveška N1 i Italija I1 izdvajaju u zasebne grupe, jer imaju uočljivo i daleko najmanje prosječne vrijednosti visine sadnica. Sa druge strane, što se tiče promjera na vratu korijena može se uočiti da se samo provenijencija Norveška N1 izdvaja u zasebnu skupinu sa daleko najmanjom vrijednosti srednjeg promjera.

Na temelju fenoloških promatranja utvrđeno je da postoji varijabilnost između svih provenijencija. Utvrđene su razlike u kretanju, trajanju i završetku pojedinih fenofaza. Kao početak vegetacije običnog bora u međunarodnom pokusu na Kupresu može se uzeti 26. Travanj, jer je kod tri provenijencije ovog dana počelo otvaranje pupova. Kod ostalih 12 provenijencija otvaranje pupova počelo je 3. svibnja, a 21. lipnja je zabilježeno da su biljke kod svih petnaest istraživanih provenijencija dospjele u posljednju fazu, tj, da imaju u potpunosti formirane iglice zelene boje.

Prvi rezultati fenoloških promatranja pokazuju da se ova istraživanja trebaju nastaviti, kako bi se procijenilo uspijevanje i genetska varijabilnost provenijencija, utvrdila ukupna genetska raznolikost običnog bora, te ponašanje i uspijevanje različitih provenijencija na danom lokalitetu.

Obični bor je genetski diferenciran prema ekološkim i vegetacijskim područjima, te pokazuje različite morfološke i fiziološke karakteristike iz različitih područja. Na to upućuje izdvajanje sjevernih provenijencija.

Rezultati istraživanja koji se dobiju u ranom juvenilnom stadiju su nepotpuni, često opterećeni različitim nedostatcima, te vrlo često drukačiji od onih dobivenih u kasnijim fazama, te je potrebno u kontinuitetu provoditi ovakva istraživanja.

\section{LITERATURA}

\section{REFERENCE}

- Ballian, D. 2000: Značaj rasadničke proizvodnje u cilju održanja i povećanja biodiverziteta, Seminar: Sjemensko - rasadnička proizvodnja u BiH - Aktualno stanje i perspektive, str. 81-84. Brčko.

- Ballian, D., E. Mujanović, A. Čabaravdić, 2009: Varijabilnosti običnog bora (Pinus sylvestris L.) u pokusu provenijencija Glasinac - Sokolac (Bosna i Hercegovina). Šumarski list 11/12: 577588.
- Ballian, D., D. Kajba, 2011: Oplemenjivanje šumskog drveća i očuvanje njegove genetske raznolikosti. Šumarski fakulteti Univerziteta u Sarajevu i Sveučilišta u Zagrebu, str, 25-29, Sarajevo - Zagreb-

- Ballian, D., S. Šito, 2017: Analysis of differences of growth and phenology of provenances of Scots pine (Pinus sylvestris) in provenance experiment at Žepče. Biosystems Diversity, 25(3): 228-235.

- Ballian D., H. Kraigher, V. Andonovski, 2017: Survival and growth of different provenances of Scots pine (Pinus sylvestris L.) in the international trial "Kupres". 70 Years faculty of forestry in Skopje- International Scientific Conference, "Sustainable forestry: fact or fiction?', 4-6 October 2017, str. 52, Skopje.

- Eriksson, G., I. Ekberg, 2001: An Introduction to Forest Genetics. SLU Repro, str. 166, Uppsala.

- Fenološki godišnjak 2016. 2017: Bosna i Hercegovina, Federacija Bosne i Hercegovine, Federalni hidrometeorološki zavod, Sarajevo, str. 4-6,

- Giertych, M. 1976: Summary of results on Scots pine (Pinus sylvestris $\mathrm{L}$,) height growth in IUFRO provenance experiments. Institute of Dendrology, str. 63 - 120, 157 - 164, Poland, Kórnik.

- Giertych, M., J. Oleksyn, 1992: Studies on genetic variation in Scots pine (Pinus sylvestris L,) coordinated by IUFRO. Silvae Genetica, 41:133-143.

- Jovanović, B. 2000: Dendrologija, Univerzitet u Beogradu, str. 104 - 135, Beograd.

- Kramer, P.J., T. Kozlowski, 1960: Physiology of Trees, McGraw - Hill, New York.

- Lojo, A., B. Balić, 2011: Prikaz površina šuma i šumskih zemljišta: Stanje šuma i šumskih zemljišta u Bosni i Hercegovini nakon provedene Druge inventure šuma na velikim površinama u periodu 2006, do 2009, godine, str. 34 - 48, Sarajevo.

- Mikić, T. 1991: Primjena metoda oplemenjivanja u podizanju intenzivnih kultura šumskog drveća u cilju povećanja proizvodnje drvne mase sa kratkim produkcionim periodom, Izvještaj za period 1989 - 1990 u okviru D.C. VII., Sarajevo.

- Milosavljević, R. 1977: Opšta klasifikacija tipova klime Bosne i Hercegovine. Šumarski fakultet u Beogradu, Katedra za ekologiju, Beograd.

- Müller-Starck, G., P.H. Baradat, F. Bergmann, 1992: Genetic variation within European tree species. New Forests, 6: 23 - 47.

- Nilsson, J.E. 1992: Growth and survival of spontaneous provenance hybrids of Pinus sylvestris. Scandinavian Journal of Forest Research, 7: 193-203.

- Nilsson, J.E., E.A. Walfridsson 1995: Phenological variation among plus-tree clones of Pinus sylvestris L, in northern Sweden. Silvae Genetica, 44: 20-28.

- Oleksyn, J. 1988: Report on the IUFRO - 1982 provenence experiment on Scots pine (P. sylvestris L,). Arborae Kóornickie, 33: 211-229.

- Omanović, M. 2008: Biohemijska karakterizacija prirodnih populacija običnog bora (Pinus sylvestris L,) u dijelu rasprostranjenja u Bosni i Hercegovini. Magistarski rad, Sarajevo.

- Pintarić, K. 2002: Šumsko-uzgojna svojstva i život važnijih vrsta drveća. Udruženje šumarskih inžinjera i tehničara $\mathrm{FBiH}$, str. 15 - 20, Sarajevo.

- Prus-Glowacki, W., J. Oleksyn, P.B. Reich, 1998: Relation between genetic structure and susceptibility to air pollution of European Pinus sylvestris populations from a IUFRO-1982 provenance experiment. Chemosphere 36: 813-818. 
- Sarvas, R. 1962: Investigations on the flowering and seed crop of Pinus sylvestris. Commun, Inst, For, Fennica, 53: 1-198.

- Stefanović, V. 1958: Areal prirodnog rasprostranjenja bijelog bora (Pinus silvestris) u NR Bosni i Hercegovini, Radovi Poljoprivredno - Šumarskog fakulteta u Sarajevu, 3: 147-195, Sarajevo.

- Stefanović, V., S. Milanović, S. Međedović, K. Pintarić, S. Rončević, D. Sisojević, 1980: Ekotipovi bijelog bora (Pinus syl- vestris L.) u Bosni, Posebna izdanja br, 13, Šumarski fakultet i Institut za šumarstvo u Sarajevu, str. 9-25, Sarajevo.

- Vidaković M., J. Franjić, 2004: Golosjemenjače, Šumarski fakultet Sveučilišta u Zagrebu, str. 411 - 417, 602 - 628, Zagreb.

- Vidaković, M., A. Krstinić, 1985: Genetika i oplemenjivanje šumskog drveća, Sveučilište u Zagrebu, Šumarski fakultet, str. 350-358, Zagreb.

\section{SUMMARY}

Analysis of differences of growth and phenology of provenances of Scots pine (Pinus sylvestris) in provenance experiment at Kupres (Bosnia and Herzegovina)

In this paper, 15 European provenance of Scot pines have been analyzed in an international experiment at Kupres. The experiment was established during the spring of 2012 with plants of two years old $(2+0)$. A total of 1,800 seedlings of ordinary Scot pine were planted in the experimental design of a casual block system adapted to the terrain, 15 provenances in five repetitions ( $5 \times 36$ seedlings). The experiment is made up of ten European countries: Austria (Traisen, Rein, Sistrans), Bosnia and Herzegovina (Bugojno), Ukraine (Ivano Frankivsk), Slovakia (Hanusovce), Romania (Sacueini), Norway (Narvik, Arnes), Germany (Teisendorf, Trippstadt), Poland (Raciane - Nida) and Italy (Ca del Lupo, Fenestrelle, Piani - Valda). The results of morphological and physiological researches relate to differences in survival, height, root neck diameter, and spring phenomenon of bud opening. The total number of seedlings measured is 1830 , with the percentage of survival in the year 2017 being $67.70 \%$, and ranging from $35.50 \%$ (Italy I1) to $87.70 \%$ (Austria A1). Descriptive analysis of the diameter of the root neck was found to have the highest mean diameter of Austria A1 $(4.07 \mathrm{~cm})$. The lowest value of the average diameter of the root neck has plants originating in Norway $\mathrm{N} 1(1.19 \mathrm{~cm})$, root diameter values ranged from $0.30 \mathrm{~cm}$ to Norway N1, which is the minimum of $9.30 \mathrm{~cm}$ for Austria A1 which represents the maximum when it comes to the average diameter of the neck of the root.

With an average height of $116.26 \mathrm{~cm}$, the provenance of Poland P1 shows the highest average value for altitude, while the plants from Norway N1 have the lowest average value for a height of $40.52 \mathrm{~cm}$.

All studies have shown a variance analysis that statistically significant differences between investigated provenances are present, as confirmed by Duncan's test.

On the basis of the analysis carried out, it can be concluded that on the basis of the height of the only $\mathrm{N} 1$ and Italy I1 provenances, they are separated into separate groups because they have noticeable and far least average values of the seedlings height. On the other hand, as far as diameter on the root of the root can be seen only the N1 Norway proves itself into a separate group with by far the smallest mean diameter.

Based on phenological observations, there is variability between all provenances. Differences in movement, duration and end of individual phenomena have been established. As a start of ordinary Scot pine tree vegetation in the international experiment on Kupres can be taken on April 26 because in the three provenances this day the opening of the buds began. In the other 12 provenances the opening of the buds began on May 3, and on 21 June it was noted that the plants in all fifteen investigated the origins have come to the final stage, that is, they have completely formed needles of green color.

The first results of the phenological observations show that these studies should continue to determine the overall genetic diversity of ordinary wrinkles, to determine the success and genetic variability of provenances, as well as the behavior and success of different provenances at a given locality.

Ordinary pine is genetically differentiated into ecological and vegetation areas, and shows different morphological and physiological characteristics from different areas. This indicates the separation of northern provenances.

The research results obtained at the early juvenile stage are incomplete, often burdened with various disadvantages, and very often different from those obtained at later stages, and such research has to be carried out in continuity.

KEY WORDS: Scot pine (Pinus sylvestris L.), provenance, survival, root neck diameter, height, phenology. 